\title{
Evaluation of welding properties of construction materials using the SEP 1390 tests
}

\author{
Keywords: \\ welding properties of materials; \\ technological tests; \\ tests of SEP 1390; \\ destructive testing
}

\begin{abstract}
Issues connected with the evaluation of weldability of thick-walled materials used to manufacture welded steel structures were brought forward in the article. Evaluation of weldability determined by analytical methods and verified in a process test according to the guidelines of SEP 1390 was presented. This test is recommended for the research of thick-walled construction materials, in particular those working under dynamic load. Hardness and metallographic tests were also conducted to assess plastic properties of the materials, very important from the point of view of weldability. The purpose of the topic taken on was the assessment of usefulness of different systems of evaluation of weldability of thick-walled construction materials intended to be used in welded structures.
\end{abstract}

\section{Introduction}

Dynamic economic development on world markets initiates many investments in such areas as construction, energy, metallurgy, raw materials industry or shipbuilding. Among these investments, one can particularly distinguish those that require the production of large-size constructions, often with the use of thick-walled elements. In these elements, designed and manufactured structural nodes require a special approach to making a variety of thick-walled welded joints that require the use of appropriate technologies and appropriate conditions for their implementation in order to obtain appropriate properties that ensure quality requirements. The basic property of materials used for welded constructions, including those made of thick-walled materials, is weldability. This concept takes on special significance with regard to welded materials requiring the use of thermal treatments, including thick-walled elements. The concept of weldability defined in various ways is directly related to the material's suitability for making a welded joint under specific conditions and using the appropriate technology to obtain a durable joint with the appropriate quality and performance features $[1 \div 6,16]$. The concept of weldability captures a wide set of factors directly affecting the final effect of the welded joint and is closely related both to the proper design of joints and their technological implementation while ensuring the proper course of metallurgical processes. In practical applications, these characteristics of the material are determined, related to the concept of weldability, using mainly analytical methods (calculation formulas), often based on the appropriate chemical composition of the material. In research systems, simulation tests are used on simulators of thermal cycles of welding. In order to verify the results of the weldability assessment obtained by analytical and research methods, technological trials that take into account many real variable manufacturing processes of basic material and welded joint, are often used. Analytical methods are the most frequently used (including the determination of the carbon equivalent value $\mathrm{C}_{\mathrm{E}}$ ) due to the cost and speed of the determination as opposed to very costly and labor-intensive simulation studies [19]. Technological tests, on the other hand, are often used to verify analytical methods to confirm the quality assumptions required by the relevant standards and guidelines. The technological tests recommended for use are often related to the phenomena of cracking or tendency of the material to crack. Such tests include, for example, the Tekken or CTS test, as well as material stretching in the "Z" axis, which tests the tendency of steel to lamellar cracks $[2 \div 4,8]$. A similar application applies also to the test defined as SEP 1390 recommended for the assessment

dr inż. Ryszard Krawczyk - Czestochowa University of Technology

Corresponding author. ryszardkrawczyk@spaw.pcz.pl 
of the weldability of construction materials with a yield range of 235 to $355 \mathrm{MPa}$ and a thickness of $30 \mathrm{~mm}[5,10,17]$. The sample described in the guidelines as SEP 1390 was previously known and is described in the literature under the name of the Kommerell sample [2,18].

The subject of the presented study is a comparative assessment of the weldability of thick-walled construction materials determined by an analytical method and a verified technological test. The SEP 1390 sample recommended for the assessment of thick-wall construction materials working under dynamic load was used for verification.

\section{Weldability assessment by analytical method}

Many dependencies apply to the assessment of weldability using analytical methods, among which dependencies based on the analysis of the chemical composition of the material predominate. They allow to determine the influence of various alloying elements on the hardenability of steel, i.e. the tendency to form hard hardening structures like mar-

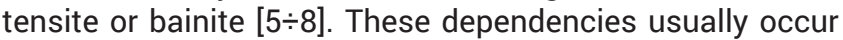
in the form of carbon equivalents developed for appropriate material groups. The most widespread and used dependences are the carbon equivalent $\mathrm{C}_{\text {ellw }}$ developed to assess the weldability of non-alloy carbon steels and high strength steels by the International Welding Institute. This dependence has the following form $[1 \div 4]$ :

$$
\mathrm{C}_{\text {elIW }}=\mathrm{C}+\frac{\mathrm{Mn}}{6}+\frac{\mathrm{Cr}+\mathrm{Mo}+\mathrm{V}}{5}+\frac{\mathrm{Ni}+\mathrm{Cu}}{15}
$$

and should reach a maximum value of up to $0.47 \%$ for materials with a thickness in the range from 40 to $150 \mathrm{~mm}$ and in addition, if the following conditions regarding the carbon content and carbon equivalent are met, depending on the thickness of the material:

$$
\begin{aligned}
& \mathrm{C} \leq 0,20 \% \text { i } \mathrm{C}_{\mathrm{e}} \leq 0,45 \% \text { and } \mathrm{g} \leq 25 \mathrm{~mm} \\
& \text { or } \\
& \mathrm{C} \leq 0,20 \% \text { i } \mathrm{C}_{\mathrm{e}} \leq 0,41 \% \text { and } 25<\mathrm{g} \leq 37 \mathrm{~mm} \text {, }
\end{aligned}
$$

then it can be assumed that no special precautions are required in the welding process. The recommendations of MIS for steel with strength of UTS $=490 \div 690 \mathrm{MPa}$ on the use of a low-hydrogen welding process must also be met. For higher material thicknesses, i.e. above $40 \mathrm{~mm}$, these conditions are met when the carbon equivalent reaches a value of $C_{e} \leq 0.40 \%$. If the above conditions are not met and there are other factors associated with significant material thickness, such as the degree of joint hardening, there is a considerable risk of a creation of hard structures and thus cold cracks $[5,6,8]$.

A similar dependence of carbon equivalent $C_{e}$ developed by the Japanese Welding Association has the following form $[1 \div 4]$ :

$$
\mathrm{C}_{\mathrm{eJ}}=\mathrm{C}+\frac{\mathrm{Mn}}{6}+\frac{\mathrm{Si}}{24}+\frac{\mathrm{Ni}}{40}+\frac{\mathrm{Cr}}{5}+\frac{\mathrm{Mo}}{4}
$$

and is designed to assess the weldability of non-alloy carbon steels and high strength steel materials, similar to the equivalent of carbon recommended by MIS.

The assessment of the weldability of the material was carried out in accordance with the previously presented guidelines for the selected material of S355J2+N type [11,12]. Samples for tests marked with $1 / 40,2 / 40$ and $3 / 40$ symbols were taken from three batches of sheet material of equal thickness equal to $40 \mathrm{~mm}$. The adopted type of material meets the requirements for both yield strength and thickness requirements. The most important data from the point of view of the experiment conducted for this steel are presented on the basis of manufacturer approvals in Table I.

Materials accepted for testing can be classified in terms of thickness, strength properties and carbon content as well as carbon equivalents $\mathrm{C}_{\text {ellw, }}, \mathrm{C}_{\mathrm{eJ}}$ as meeting all the requirements of PN-EN 10025-2: 2008.

\section{Weldability assessment in the SEP 1390 technological test}

In order to verify the welding properties assessment of thick-walled materials obtained by analytical methods, a technological crack resistance test was carried out according to SEP 1390.

Samples were taken from each batch of material in accordance with the scope given in SEP 1390 and related to the type of material and its thickness $[9,10]$. The samples were cut and machined to the correct dimensions together with the $\mathrm{R} 4$ radius groove in accordance with the diagram shown in Figure 1.

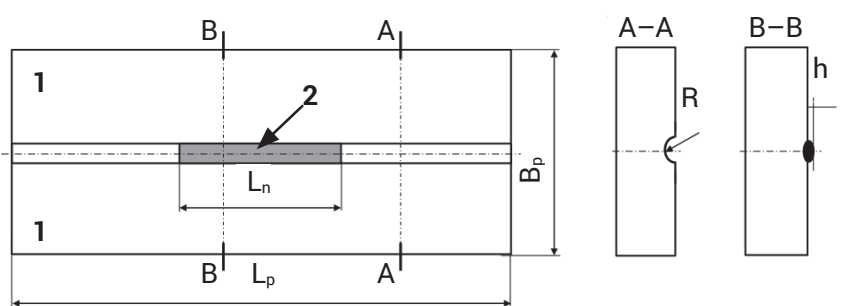

Fig. 1. Diagram of the specimen for the assessment of weldability in the SEP 1390 test, 1 - tested material, 2 - overlay weld $[9,17]$

The padding welds on the samples were made according to the scheme in Figure 1 using the manual arc welding method with rutile thick-covered electrode OK FEMAX 33.80 with a $5 \mathrm{~mm}$ core diameter [13]. The dimensions of samples and pads made with a continuous bead without interruption are given in Table II.

The view of the sample prepared for the test before making the padding weld and with a finished padding weld is shown in Figure 2.

\begin{tabular}{|c|c|c|c|c|c|c|}
\hline $\begin{array}{c}\text { Sample } \\
\text { designation }\end{array}$ & $\begin{array}{c}\text { Material thickness } \\
\text { t [mm] }\end{array}$ & $\begin{array}{l}\text { Yield Stress } \\
\text { YS [MPa] }\end{array}$ & $\begin{array}{c}\text { Ultimate Tensile } \\
\text { Strength UTS [MPa] }\end{array}$ & $\begin{array}{c}\text { Carbon content } \\
\text { C [\%] }\end{array}$ & $\begin{array}{l}\text { Carbon equiva- } \\
\text { lent } \mathrm{C}_{\mathrm{ellw}}[\%]\end{array}$ & $\begin{array}{l}\text { Carbon equiva- } \\
\text { lent } \mathrm{C}_{\mathrm{eJ}}[\%]\end{array}$ \\
\hline $1 / 40$ & 40 & 355 & 554 & 0,16 & 0,42 & 0,42 \\
\hline $2 / 40$ & 40 & 363 & 567 & 0,17 & 0,42 & 0,43 \\
\hline $3 / 40$ & 40 & 376 & 586 & 0,18 & 0,43 & 0,44 \\
\hline
\end{tabular}

The scheme of conducting the weldability test in the bending test according to SEP 1390 is shown in Figure 3, and the relevant dimensions in Table III. The bending tests

Table I. Characteristic data for S3553J2N steel $[11,12]$ 
were carried out under static loading conditions on the Heckert EU100T testing machine using the appropriate tooling (Fig. 3). The view of the sample before the start of the test set in a special bending device for thick-walled materials is shown in Figure 4.

Table II. Dimensions of the type series of the specimen samples depending on the thickness of the tested material $[9,17]$

\begin{tabular}{|c|c|c|c|c|}
\hline $\begin{array}{c}\text { Material } \\
\text { thickness } \\
\mathbf{g}[\mathrm{mm}]\end{array}$ & $\begin{array}{c}\text { Length } \\
\text { of the } \\
\text { sample } \\
\mathrm{L}_{\mathrm{p}}[\mathrm{mm}]\end{array}$ & $\begin{array}{c}\text { Width } \\
\text { of the } \\
\text { sample } \\
\mathrm{B}_{\mathrm{p}}[\mathrm{mm}]\end{array}$ & $\begin{array}{c}\text { Length } \\
\text { of the pad- } \\
\text { ding weld } \\
\mathbf{L}_{n} \text { min [mm] }\end{array}$ & $\begin{array}{c}\text { Radius } \\
\text { of the } \\
\text { groove } \\
\mathbf{R}[\mathrm{mm}]\end{array}$ \\
\hline 40 & 440 & 200 & 190 & 4 \\
\hline
\end{tabular}
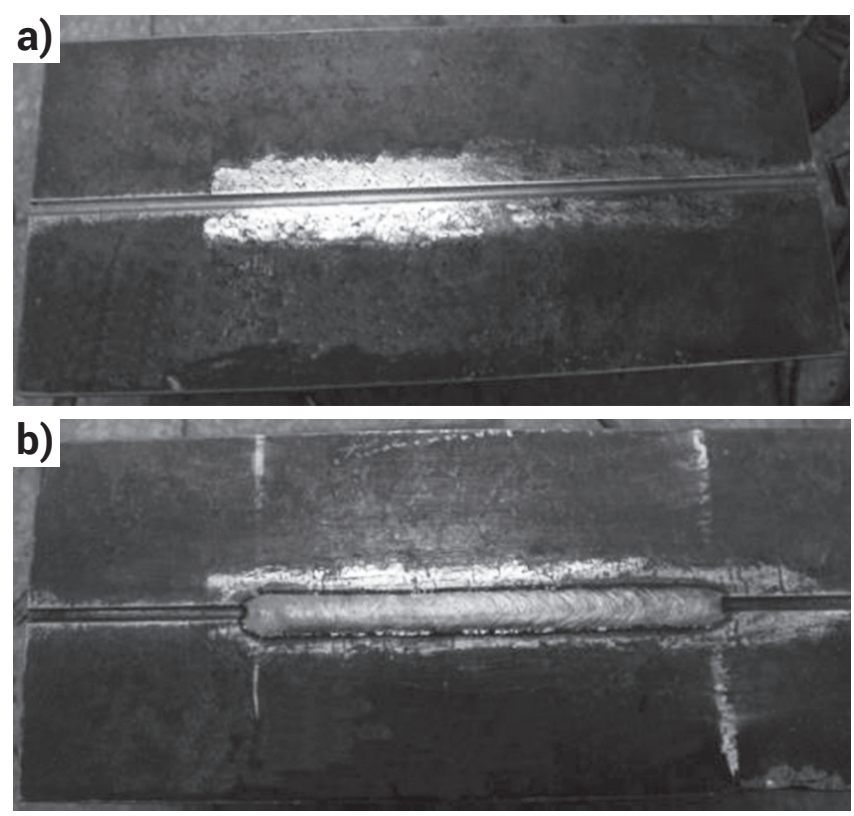

Fig. 2. View of the tested sample before surfacing welding (a) and with an executed surfacing weld (b)

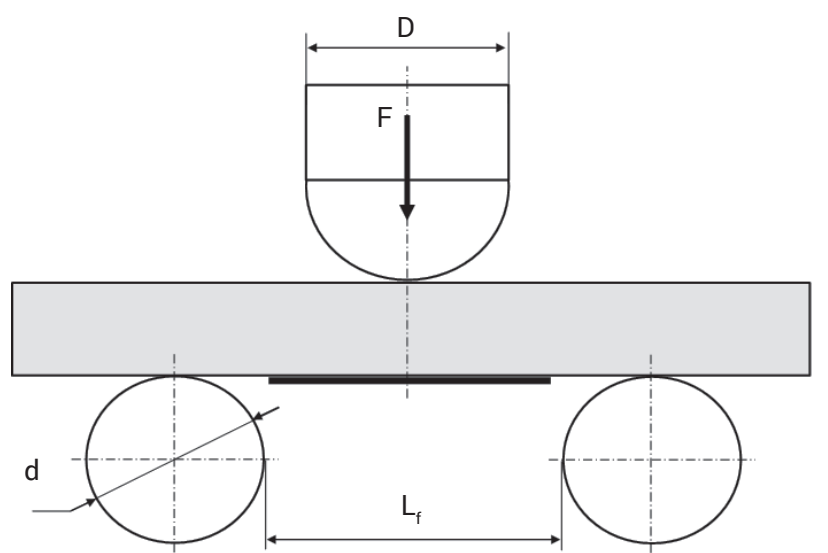

Fig. 3. Diagram of the conduct of the weldability assessment in the bend test SEP $1390[9,17]$

Table III. Dimensions for the diagram of the test according to SEP $1390[9,17]$

\begin{tabular}{|c|c|c|c|}
\hline $\begin{array}{c}\text { Thickness } \\
\mathbf{g}[\mathbf{m m}]\end{array}$ & $\begin{array}{c}\text { Mandrel's } \\
\text { diameter } \\
\text { D [mm] }\end{array}$ & $\begin{array}{c}\text { Distance } \\
\text { of the supports } \\
\mathrm{L}_{\mathrm{f}}[\mathrm{mm}]\end{array}$ & $\begin{array}{c}\text { Diameter } \\
\text { of the supports } \\
\text { d [mm] }\end{array}$ \\
\hline 40 & 120 & 220 & $\geq 50$ \\
\hline
\end{tabular}

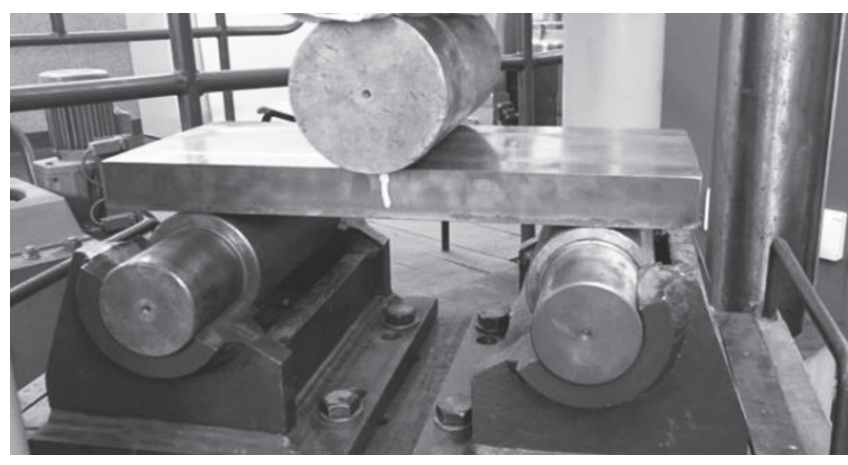

Fig. 4. View of the samples in the bending device placed in the strength testing machine

During the bending course to the $60^{\circ}$ limit angle, the tensile zone was observed by monitoring the formation of cracks in the weld and their development in the material as shown in Figure 5. The purpose of the monitoring was to initially assess the correctness of the test run and to capture the moment of stopping of the test when the breaking limit was greater than $80 \mathrm{~mm}$ from the padding weld's axis.

The samples after bending tests were evaluated by inspecting the surface of the sample with the padding weld and measuring the length of the cracks in relation to the weld axis. In order to obtain a better resolution, penetrant tests were carried out on the examined surface when assessing the crack size.

The samples after bending tests were evaluated by inspecting the surface of the sample with the padding weld and measuring the length of the cracks in relation to the weld axis. In order to obtain a better resolution, penetrant tests were carried out on the examined surface during the assessment of the crack size. The assessment was carried out in accordance with the requirements of the SEP 1390 test guideline, assuming a positive situation where at least one crack occurred in the padding weld, which exceeded the heat affected zone (HAZ) of the padding weld and was blocked in the native material of the sample, and the maximum crack length did not exceed $80 \mathrm{~mm}$. If the crack length is more than $80 \mathrm{~mm}$, the sample should be classified as negative. On the other hand, if during a bending test no crack is caused or the resulting crack does not exceed the HAZ and is not found in the native material, the test should be considered invalid and must be repeated.

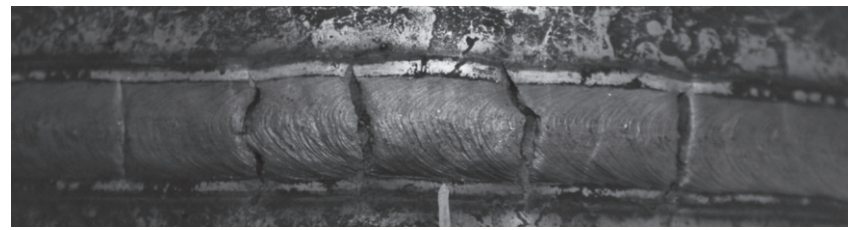

Fig. 5. View of the cracks formed in the overlay weld of the bent sample

If the test for the material tested is negative, the material should be excluded or two new material samples should be taken from the same control group and tested again. In order to obtain a positive result in repeated tests, both samples tested must meet the requirements.

The view of the samples after the bending, visual and penetration tests are presented in the following Figures 6 , 7 and 8.

The five cracks visible in Figure 6 were formed in sample No. $1 / 40$ subjected to bending to an angle of $60^{\circ}$. The maximum length of the crack passing from the axis of the weld through the HAZ to the blocking in the material of the plate 


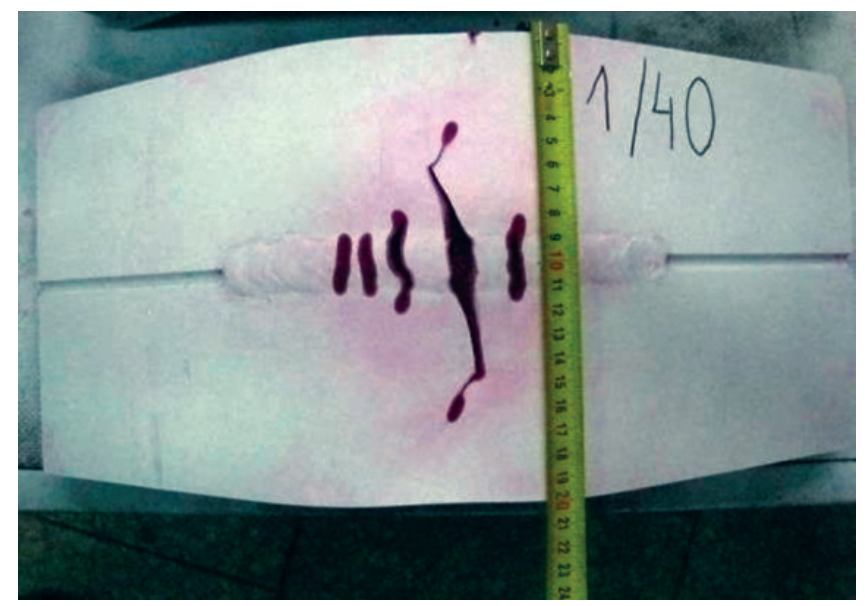

Fig. 6. View of the indications in penetration tests of sample 1/40

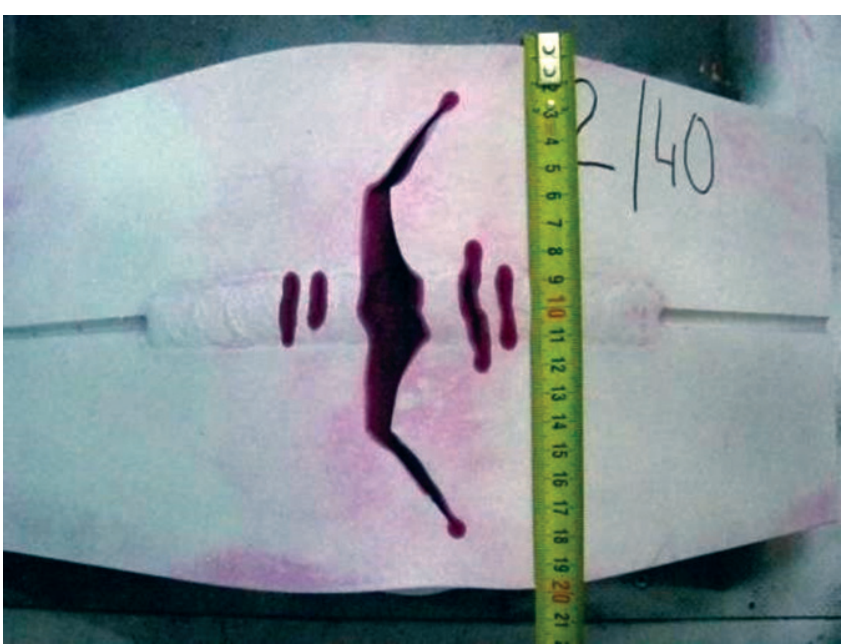

Fig. 7. View of the indications in penetration tests of sample 2/40

is $63 \mathrm{~mm}$. The required weldability criteria specified in the $1 / 40$ test has been met for this material.

The five cracks shown in Figure 7 were also formed in sample No. 2/40 subjected to bending to an angle of $60^{\circ}$. The maximum crack length passing from the axis of the weld through the HAZ to the blocking in the material of the plate is $76 \mathrm{~mm}$. The required weldability criterion specified in test number $2 / 40$ has been met for this test material.

Only one crack visible in Figure 8 was made in sample No. $3 / 40$ subjected to bending to an angle of $55^{\circ}$. During the course of the bending test, a stepwise three-step development of the crack was observed, starting from $30^{\circ}$ to the final $55^{\circ}$. This atypical abrupt crack development reflects the varied surface of the breakthrough with visible crack focal zone, resting lines defining rapid crack growth and temporary breakthrough. Individual zones have the structure of a mixed breakthrough with the predominance of brittle material in the upper part, and in the lower part with the domination of plastic material, as shown in Figure 9. The final length of the resulting crack passing from the axis of the weld through the HAZ and unblocked in the material of the plate is 100 $\mathrm{mm}$. On the half of the width of the sample crack occurred throughout the material. In this test, the required bending angle of $60^{\circ}$ was not obtained and the length of the resulting crack exceeded the limit value of $80 \mathrm{~mm}$. Therefore, the required weldability criterion specified in sample number $3 / 40$ was not met for this test material.

The conducted technological tests on samples taken from three different batches of materials (from three different melts) of the same type of material $($ S355J2+N) with similar strength properties confirmed good welding properties in two cases (test no. 1/40 and 2/40), while in the third case - unfavorable welding properties (test no. 3/40). The results confirm different material's ability to block the crack initiated in them despite similar properties. From this point of view, it is also interesting to assess the level of plasticity of the material responsible for blocking cracks. Assessment of plasticity should be carried out both for the material itself and in the area of the padding weld.

Vickers and metallographic tests were used to assess the plasticity of the material. To carry out these tests, samples were taken from materials used in the SEP 1390 test from the end sections not subjected to bending deformations.

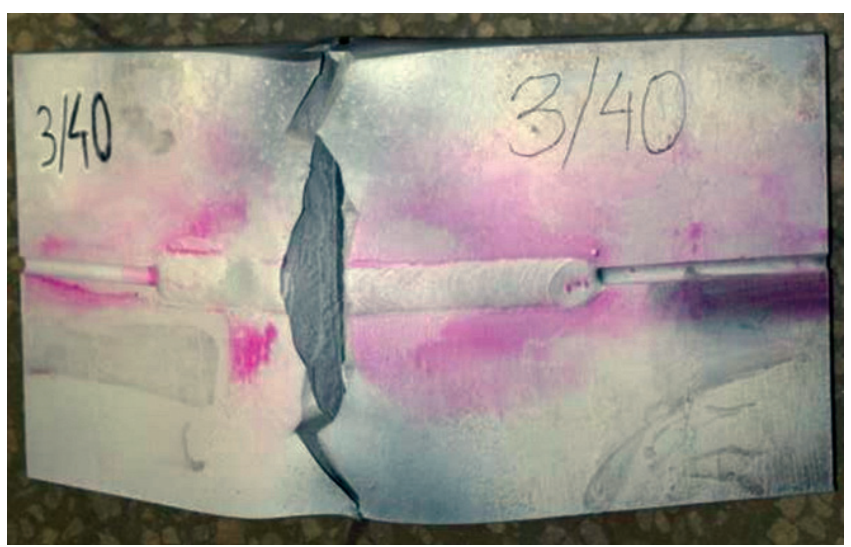

Fig. 8. View of the crack after bending sample $3 / 40$

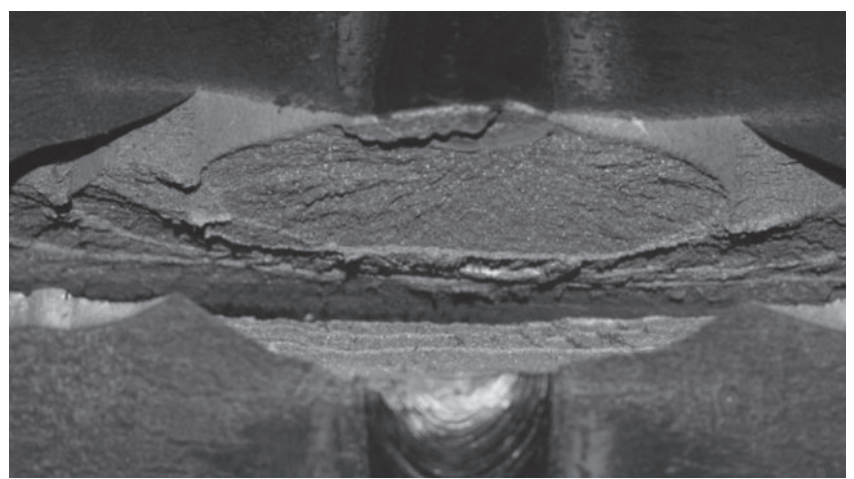

Fig. 9. View of the crack's fracture after bending sample $3 / 40$

\section{Hardness Measurements}

For the hardness test, sections from the central zone of individual samples of SEP 1390 were collected to cover the padding weld. Macroscopic specimens were made on the surface of the collected samples to reveal the cross-section of the padding weld and the heat affected zone. The maximum width of heat affected zones was measured on the prepared macroscopic specimens, which are $1.9 \mathrm{~mm}$ for $1 / 40$ and $2 / 40$ samples and $2.2 \mathrm{~mm}$ for the $3 / 40$ sample. The view of one of the samples with the macroscopic specimen is shown in Figure 10.

Hardness measurements were made using the Vickers method on a stationary hardness tester of HPO 250 type in accordance with the requirements of PN-EN ISO 9015-1 by performing at least three measurements in each zone, i.e. in the padding weld, HAZ and in the native material. The results of the maximum hardness tests are presented in Table IV.

The results of the tests carried out showed the hardness values in the padding weld at the same level in all of the samples, while quite significant differences were found in the HAZ and minor differences in the native material. 
Table IV. Results of the maximum values of the HV (Vickers Pyramid Numbers) determined for the individual zones

\begin{tabular}{|c|c|c|c|}
\hline $\begin{array}{c}\text { No. } \\
\text { of the sample }\end{array}$ & Padding weld & HAZ & $\begin{array}{c}\text { Native } \\
\text { material }\end{array}$ \\
\hline $1 / 40$ & 235 & 290 & 172 \\
\hline $2 / 40$ & 233 & 310 & 174 \\
\hline $3 / 40$ & 232 & 339 & 180 \\
\hline
\end{tabular}

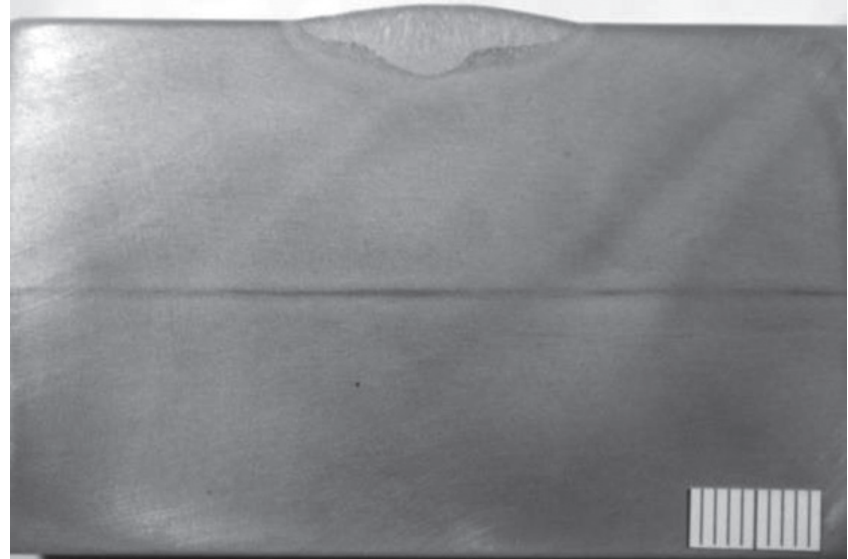

Fig. 10. View of the material sample with surfacing weld in a macroscopic section: magnification $\mathrm{x} 1.5$, etchant (corrosive reagent): nital; dark band visible in the middle zone

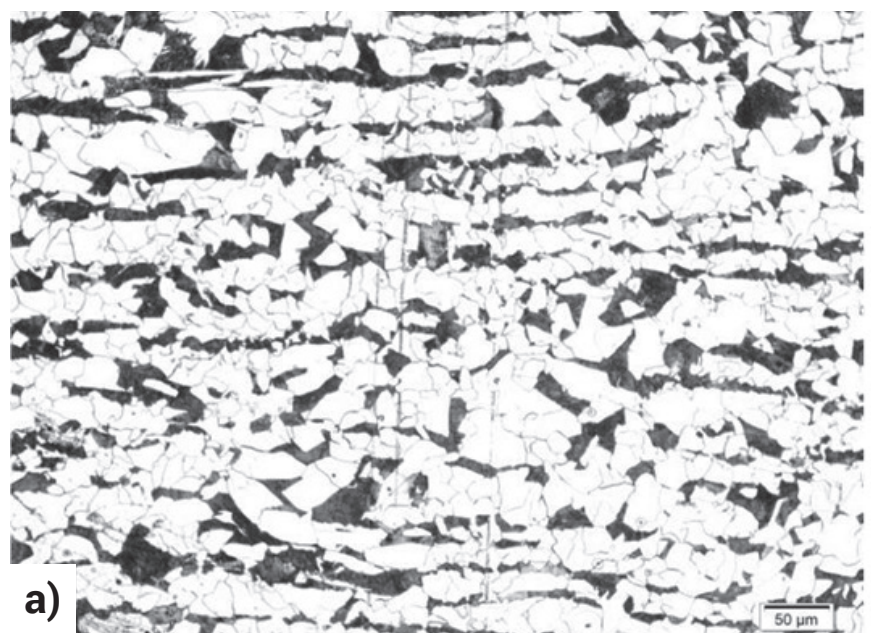

\section{Microscopic examinations}

Microscopic examinations were carried out in accordance with the requirements of PN-EN ISO 17639 [15]. The surfaces of the samples were subjected to digestion with the nital reagent, and the observation of the structures was carried out using the OLYMPUS GX 51 digital microscope with $x 50, x 200$ and $x 500$ magnifications. Sample images of microstructures for native material with a magnification of x200 are shown in Figure 11.

The basic material of $5355 \mathrm{~J} 2+\mathrm{N}$ steel outside the heat affected area has a ferrite-perlitic structure in the band system shown in Figure $11 \mathrm{a}$. On the other hand, in the heat-affected zone, i.e. at the end of the HAZ (in the zone of partial normalization) pearlite (a structural component with a lower transformation temperature) was recrystallized, creating a fine-grained ferrite-pearlite structure.

In the following Figures 12,13 and 14 the microstructures of the transition area between the HAZ and the padding weld along the fusion line for samples 1/40, 2/40 and 3/40 are shown. Images of microstructures are presented in enlargements $x 200$ in figures (a) and x500 in figures (b).

The padding welds structure of $1 / 40,2 / 40$ and $3 / 40$ samples is ferritic-perlitic with a visible outline of a columnar primary structure oriented towards the outflow of heat. There is a polygonal ferrite on the boundaries of former austenite grains, and fine-acicular ferrite inside the former austenite grains. Near the fusion line, thicker grains appear in the structure. In all samples tested on the other side of the fusion line,

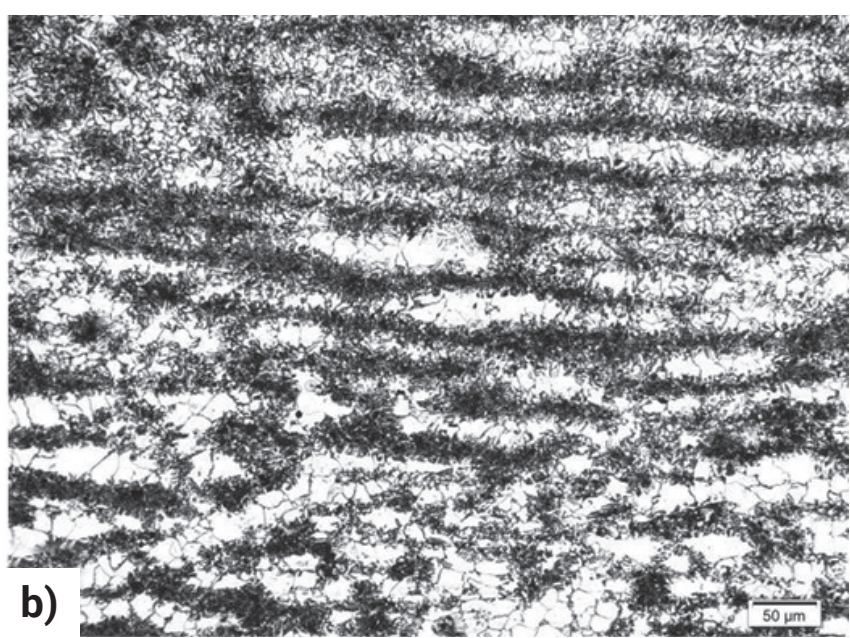

Fig. 11. Microstructure of native material in x200 magnification: a) from the area outside the overheat zone, b) in the overheat zone near the HAZ
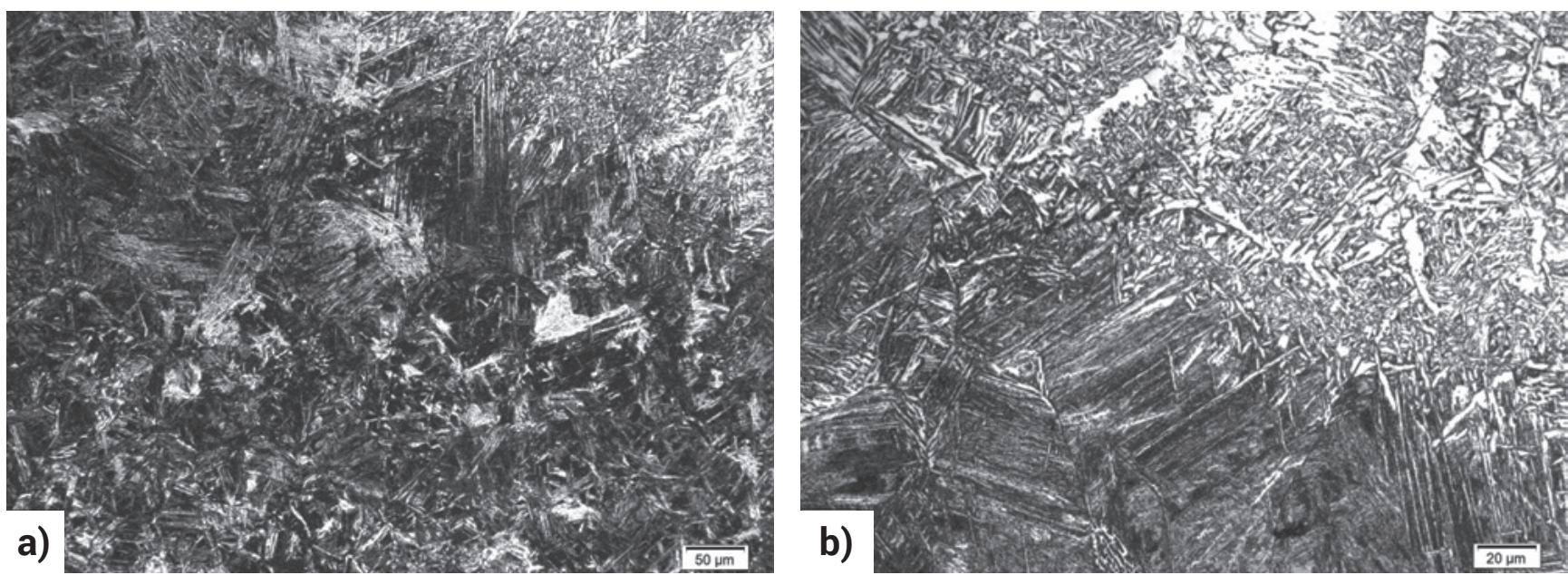

Fig. 12. Microstructure of the HAZ transition area and overlay weld on the sample no. $1 / 40$ at a magnification of: a) $\times 200$ b) $\times 500$ 

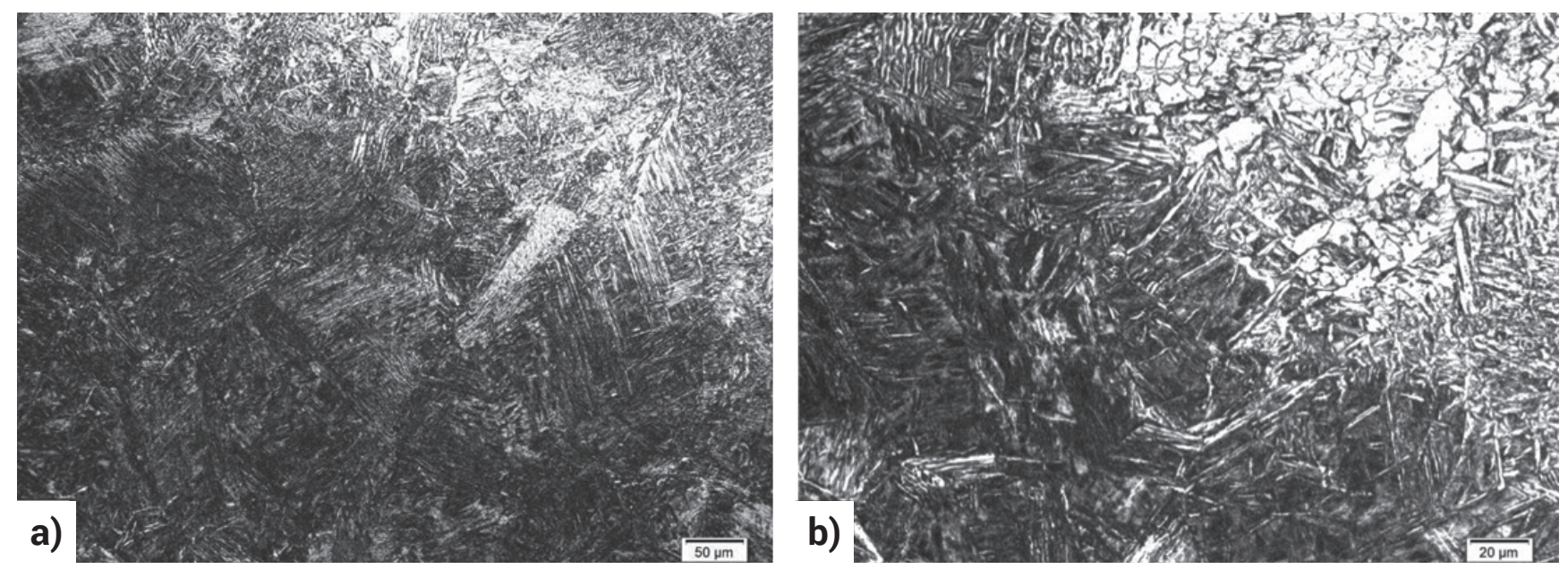

Fig. 13. Microstructure of the HAZ transition area and overlay weld on the sample no. 2/40 at a magnification of: a) x200 b) x500
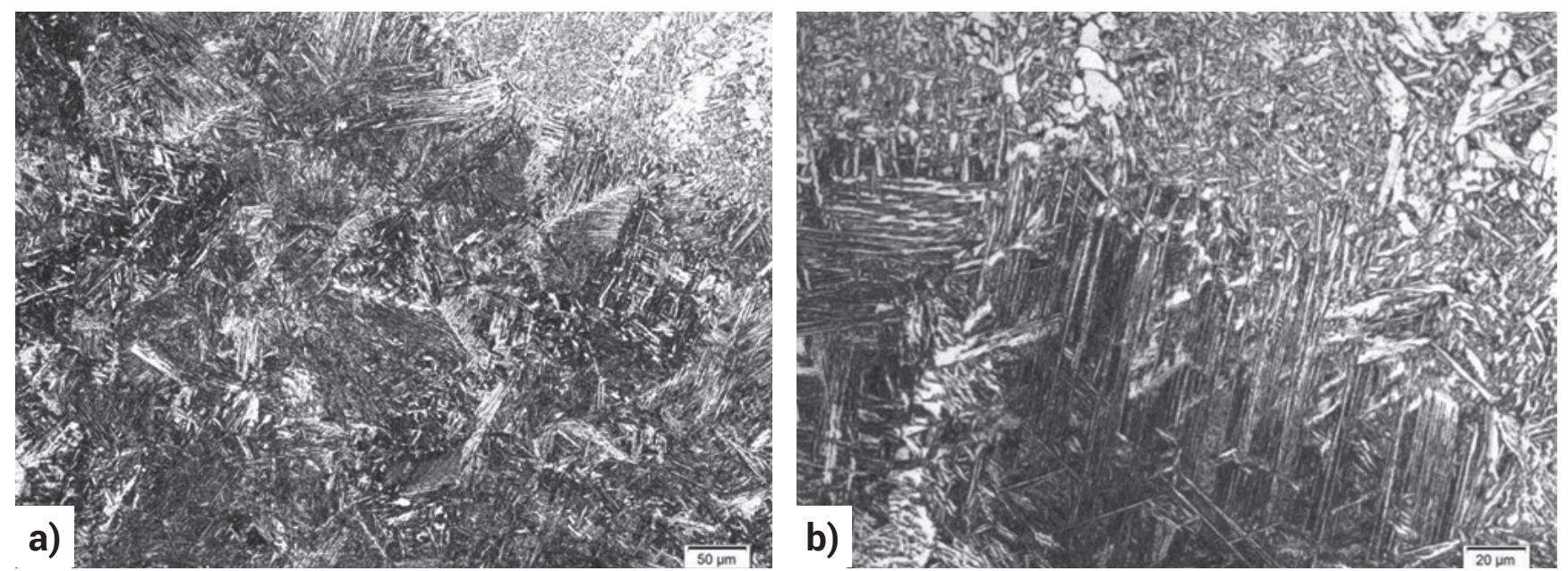

Fig. 14. Microstructure of the HAZ transition area and overlay weld on the sample no. $3 / 40$ at a magnification of: a) $x 200$ b) $x 500$

i.e. in the $\mathrm{HAZ}$, there is a diverse structure depending on the degree of material overheating and the intensity of heat dissipation. In the immediate vicinity of the fusion line, in the area of high overheating, there is a thick-acicular bainitic-ferritic structure with ferrite elements in the Widmanstetten system and martensite needles. The most characteristic long and thin needles are found in the fusion line in sample No. 3/40. The farther from the fusion line towards the basic material, i.e. towards the lower level of overheating, the more the ferritic-pearlitic structure dominates with the smaller amount of bainite.

\section{Analysis of the results}

Weldability assessment by analytical method based on carbon content $C$ and carbon equivalents $C_{e}$ determined by MIS $C_{\text {ellw }}$ and the Japanese Welding Association $C_{e J}$ for all tested materials showed that the criterion adopted for materials with good weldability, i.e. $C_{e} \leq 0.40 \%$, was exceeded. Due to different content of carbon in steel and different values of carbon equivalents, materials have different levels of welding properties. On this basis, the assessed materials should be included in the group with limited weldability. In turn, conducted technological tests of individual materials in accordance with the guidelines of SEP 1390 showed a positive assessment of welding properties for tests no. $1 / 40$ and $2 / 40$, and negative for the test no. $3 / 40$. A set of the most important data from the analysis and conducted SEP research for individual tests:
- test no. $1 / 40$ - carbon content $C=0.16 \%$, carbon equivalent $\mathrm{Ce}=0.42 \%$, maximum crack length $63 \mathrm{~mm}-$ positive result in the assessment of weldability;

- test no. $2 / 40$ - carbon content $\mathrm{C}=0.17 \%$, carbon equivalent $\mathrm{Ce}=0.42 \div 0.43 \%$, maximum crack length $78 \mathrm{~mm}$ (near the unacceptable limit) - positive result in the assessment of weldability;

- test no. $3 / 40$ - carbon content $\mathrm{C}=0.18 \%$, carbon equivalent $\mathrm{Ce}=0.43 \div 0.44 \%$, maximum crack length $100 \mathrm{~mm}$ (total fracture) - negative result in the assessment of weldability.

Based on the results presented above, an analysis was made of the relationship between the crack length in the SEP test and the carbon content in steel and carbon equivalents determined by the MIS and JSS relationships. The determined dependencies of the crack length $L$ together with the determination of the correlation coefficient are presented below:

for $C_{\text {ellw }}$ wg MIS $L=29500^{\circ} C_{\text {ellw }}-1169$

for $C_{e J}$ wg JSS $L=1850 \cdot C_{e J}-715$

for $C \quad L=1850 \cdot C-234$

where $R^{2}=0,84$ where $R^{2}=0,99$ where $R^{2}=0,99$

The highest correlation coefficients indicating very high reliability were obtained for the determined $L$ dependencies as a function of the carbon content $\mathrm{C}$ and the carbon equivalent $\mathrm{C}_{\mathrm{eJ}}$ determined according to the Japanese Welding Association.

The obtained hardness test results, presented in Table IV, do not exceed the limit value for this material group, i.e. $380 \mathrm{HV}$ adopted in PN-EN ISO 15614-1 regarding the qualification of welding technology. The highest level of hardness was found 
in the heat affected zone, significantly lower in the padding weld, and the lowest in the native material. In addition, the highest hardness values in HAZ and native material were found in sample No. 3/40, which is also characterized by the widest heat affected zone. The analysis carried out between hardness in HAZ, carbon equivalents and carbon content in steel showed the following relationships:

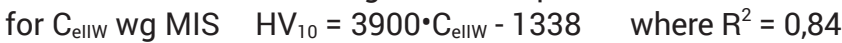
for $C_{\text {eJ }}$ wg JSS $\quad H V_{10}=2450{ }^{\circ} C_{\text {eJ }}-741 \quad$ where $R^{2}=0,99$ for $\mathrm{C} \quad \mathrm{HV}_{10}=2450 \cdot \mathrm{C}-104 \quad$ where $\mathrm{R}^{2}=0,99$

As in the previous analysis, the highest correlation coefficients indicating very high reliability were obtained for the determined HV 10 dependencies as a function of the carbon content $\mathrm{C}$ and the carbon equivalent $\mathrm{C}_{\mathrm{e} J}$ determined according to the Japanese Welding Association. The limits of carbon content and carbon equivalent $\mathrm{C}_{\mathrm{e} J}$ determined on the basis of these relationships for the limit value HV $10=380$ are respectively:

$\mathrm{C}=0,1976 \%$

$\mathrm{C}_{\mathrm{eJ}}=0,4586 \%$;

$\mathrm{C}_{\text {elIw }}=0,4405 \%$

The determined limit values $\mathrm{C}$ and Ce very accurately reflect the limit values recommended in the literature for these parameters, i.e. $\mathrm{C} \leq 0,2 \%$ and $\mathrm{C}_{\mathrm{e}} \max <0,47 \%$.

Microscopic analysis showed a large similarity of structures in the areas of native material and padding weld for all samples, while in the HAZ only for tests No. 1/40 and 2/40. In test No. 3/40, in the HAZ, an increased number of long martensite needles, which could form slip planes favorable for the development of the crack, were found next to the fusion line. Differences in this area are also confirmed by the obtained hardness results for this sample and its different behavior during bending in the SEP1390 test.

\section{Summary}

The paper presents a comparative assessment of welding properties of thick-walled construction materials using the analytical method and technological test SEP 1390. The assessment was carried out for sheets with a thickness of 40 mm made of structural steel S355J2 + N. The material tested came from three different heats with similar chemical and mechanical properties. The evaluation of welding properties of the tested materials, carried out using the analytical method and verified by the technological test SEP 1390, coincided with samples No. 1/40 and 2/40. However, In the sample No. 3/40 a positive assessment was obtained in the analytical method and negative in the technological test SEP 1390. The material in the test No. $3 / 40$ was characterized by the highest content of carbon and carbon equivalent and the highest hardness in HAZ, which was also confirmed by microscopic tests. The above factors undoubtedly had a significant impact on the welding properties of this material and a different course of the technological test SEP 1390. The tests carried out and the results obtained allowed to determine the relationship between the crack length in the SEP 1390 test, the content of carbon and carbon equivalent. Similar relationships were determined for the maximum HV 10 hardness in the HAZ zone. The determined dependences were used to calculate the limit $C$ and $C_{e}$ values at the permissible hardness required for welded joints, and the results coincide with those recommended, which fully confirm their suitability in technological applications.

In conclusion, it should be stated that the technological test SEP 1390 fully confirms its suitability for the assessment and verification of welding properties for thick-walled construction materials. Its big advantage is the use of a much larger number of variables in relation to the analytical assessment, because apart from the chemical composition, metallurgical factors, including impurities and all kinds of defects occurring at the material production stage are also taken into account.

\section{References}

[1] Praca zbiorowa, Poradnik inżyniera - Spawalnictwo tom II, Wydawnictwo Naukowo-Techniczne (2005), Warszawa

[2] S. Butnicki, Spawalność i kruchość stali, Wydawnictwo Naukowo-Techniczne (1979), Warszawa.

[3] J. Brózda, Stale konstrukcyjne i ich spawalność, Instytut Spawalnictwa (2009), Gliwice.

[4] E. Tasak, Spawalność stali, Fotobit (2002), Kraków.

[5] M. Myśliwiec, Cieplno-mechaniczne podstawy spawalnictwa, Wydawnictwo Naukowo-Techniczne (1972), Warszawa.

[6] J. Węgrzyn, Fizyka i metalurgia spawania, Politechnika Śląska (1990), Gliwice.

[7] J. Mikuła, Analityczne metody oceny spawalności stali, Zeszyty Naukowe Politechniki Krakowskiej, seria Mechanika (2001), Nr 85, Kraków.

[8] Wytyczne ABV SEP 1390:1996.

[9] R. Pakos, Technologiczna próba spawalności według ABV-SEP 1390 Przegląd Spawalnictwa (2013), vol. 85(4), 14-17.

[10] PN-EN 10025-2:2008 Wyroby walcowane na gorąco ze stali konstrukcyjnych - Część 2: Warunki techniczne dostawy stali konstrukcyjnych niestopowych.

[11] Świadectwo odbioru wytwórcy 3,1; blacha t40; S355J2+N.
[12] Atest wytwórcy materiałów spawalniczych, elektroda OK FEMAX 33.80.

[13] PN-EN ISO 9015-1:2011 Badania niszczące złączy spawanych metali - Badanie twardości - Część 1: Badanie twardości złączy spawanych łukowo.

[14] PN-EN ISO 15614-1:2008 Specyfikacja i kwalifikowanie technologii spawania metali - Badanie technologii spawania - Część 1: Spawanie łukowe i gazowe stali oraz spawanie łukowe niklu i stopów niklu.

[15] PN-EN ISO 17639:2013-12 Badania niszczące spawanych złączy metali - Badania makroskopowe i mikroskopowe złączy spawanych.

[16] R. Krawczyk, An analysis of the quality of the thick-walled S355J2+n steel joint welded by the MAG method, Archives of Metallurgy and Materials (2017), vol. 62(2), 833-839.

[17] R. Krawczyk, J. Kozłowski, Analiza wpływu zmian geometrii napoiny na przebieg próby SEP 1390, Biuletyn Instytutu Spawalnictwa w Gliwicach (2016), vol. 60(4), 72-76.

18] J. Kozłowski, Próba Kommerella, a wytyczne SEP 1390:1996, Welding Technolgy Review (2018), vol. 90(5), 86-89.

[19] K. Wojsyk, R. Krawczyk, D. Wierzchowski, Spawalnicze naprężenia i odkształcenia w konwencjonalnych ścianach szczelnych oraz ekranach nowej generacji, Welding Technolgy Review (2018), vol. 90(4), 20-23. 